\title{
Санкт-Петербург - крупномасштабные градостроительные проекты на берегу Финского залива
}

\author{
Б.Энгель, КИТ, Карлсруэ, Германия \\ А.Малько, ИРНИТУ, Иркутск, Россия
}

Проблемы городского планирования в Санкт-Петербурге носят комплексный характер, к ним относится как необходимость строительства нового жилья и реконструкции микрорайонов панельной застройки, так и преобразование многочисленных промышленных зон, обновление и расширение транспортной инфраструктуры и многое другое. Три крупномасштабных градостроительных проекта меняют силуэт Санкт-Петербурга на Финском заливе: Балтийская жемчужина на юге, Лахта-центр с башней Газпрома на севере и «Голден-Сити» (Golden City) в новом порту для круизных лайнеров. На данный момент не прослеживается общая концепция пространственного развития прибрежной зоны города. Для устойчивого развития Санкт-Петербурга необходим сдвиг парадигмы в городском планировании ${ }^{1}$.

Ключевые слова: Санкт-Петербург, городское развитие, Балтийская жемчужина, «Голден-Сити» (Golden City), Перспективный план развития города, трансформация, «Лахтацентр», «Морской фасад», силуэт, рекультивация.

\section{St. Petersburg - Large Scale Projects at the Waterfront at the Gulf of Finland}

B.Engel, KIT, Karlsruhe, Germany

A.Malko, INRTU, Irkutsk, Russia

The challenges in urban planning in St. Petersburg are complex, they include the necessary construction of new residential areas and renovation of the existing housing stock as well as the conversion of the numerous industrial areas, the renewal and expansion of the traffic infrastructure and much more. Three large-scale projects change the silhouette of St. Petersburg on the Gulf of Finland - the Baltic Pearl in the south, the Lakhta Center with Gazprom Tower in the north and the Golden City at the new port for cruise ships on Vasilevskiy Island. An overall strategic concept for the development of the waterfront is not insight. Future sustainable development of St. Petersburg requires a paradigm shift in urban planning.

Keywords: St. Petersburg, Urban Development, Baltic Pearl, Golden City, Planning strategy, transformation, Lakhta-Center, marine facade, silhouette, recultivation.

${ }^{1}$ Авторская редакция статьи «Golden-City St.-Petersburg», опубликованной в журнале «Баувельт» (Bauwelt), 2020, № 6 (источник: https://www. bauwelt.de/das-heft/heftarchiv/Glaenzende-Golden-City-St.-PetersburgBaltic-0stsee-3512665.html).
Санкт-Петербург знаменит своим городским историческим центром с уникальными историческими памятниками и музеями, разводными мостами и каналами, великолепными парками и площадями, известными университетами, исследовательскими институтами и всемирно признанной культурной и художественной сценой. Санкт-Петербург, наряду с Москвой, является важнейшим торговым, финансовым и экономическим центром России, привлекательным для иностранных инвестиций. При всём этом город остаётся важным промышленным центром. С началом постсоветского периода всё большее значение приобретают такие сферы деятельности, как услуги связи, финансов и туризма, а также высокотехнологичные и информационные технологии. Благодаря своему географическому положению город Санкт-Петербург (имеющий на сегодняшний день второй по величине морской порт в России) всегда был важным стратегическим пунктом страны и «окном России в Европу». За счёт своей близости к Скандинавии, балтийским и западноевропейским странам город является важным экономическим и туристическим центром (рис. 1).

С момента распада Советского Союза в Санкт-Петербурге начался процесс трансформации, который продолжается и по сей день, это проявляется не только в экономических и социальных переменах, но и в пространственных (территориальных) изменениях города. Наследие советской эпохи и сегодня продолжает оказывать влияние на традиционные инструменты планирования использования земельных ресурсов и отраслевой инфраструктуры, а также финансового управления. Очевидны неэффективность моделей землепользования и непрозрачность приватизационных процессов. В то же время при сравнении с долгими годами планового развития создаётся впечатление, что сейчас воцарились подходы, основанные на принципах невмешательства, индивидуальных интересах и интересах рынка, которые и определяют судьбу городского развития.

Как и многие другие мегаполисы, Санкт-Петербург остро нуждается в новой жилой площади. Общая численность населения города около 5,3 миллионов человек, несмотря на сравнительно невысокий прирост населения, средняя жилая площадь на человека в Санкт-Петербурге составляет всего 21 кв. м и всё ещё ниже общероссийского уровня [1]. Нехватка жилья - не новая проблема, а скорее следствие постоянного недостаточного инвестирования в жилищное строительство ещё с советских времен. При этом целенаправленная государственная политика в отношении социально приемлемого жилищного строительства до сих пор отсутствует [2]. Чтобы 
противостоять сложившейся сложной ситуации, ведётся интенсивное строительство. За крупными жилыми массивами на окраинах строятся новые многоэтажные микрорайоны, к

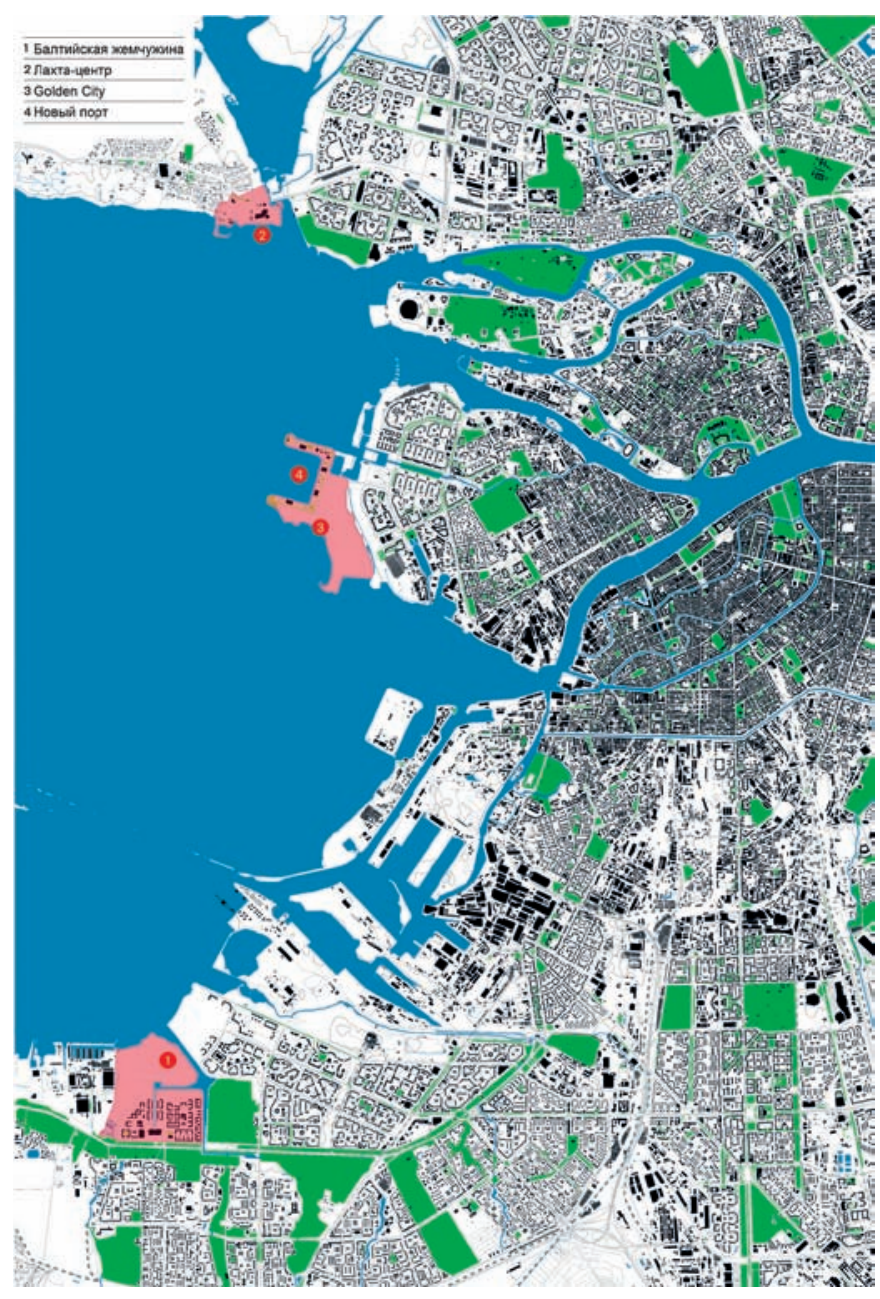

Рис. 1. Протяжённая прибрежная территория СанктПетербурга значительно изменилась за последние годы с появлением новых зданий [источник: авторская схема на основе материалов «ОпенСтритМэn» (॰0penStreetMap), «Швариплан.еу» (Schwarzplan.eu)]

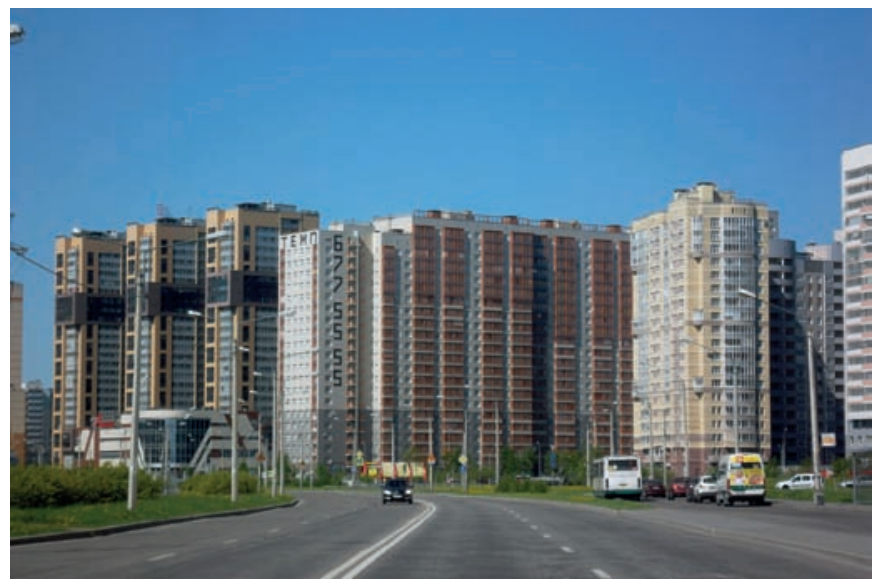

Pис. 2. «Парнас» - типичный новый район на севере СанктПетербурга. Фото Барбары Энгель. 2016 год примеру, на 2020 год запланировано строительство около 100000 квартир [3]. Многие из новых микрорайонов плохо обеспечены соответствующей инфраструктурой (не хватает таких объектов, как школы, детские сады и т.д.) (рис. 2).

\section{Стратегия 2035}

Проблемы городского планирования комплексны, они касаются не только строительства необходимого нового жилья, но и реконструкции многих существующих микрорайонов панельной застройки советского времени, составляющих около 40\% жилищного фонда города [4]. Данные проблемы включают обновление и расширение транспортной инфраструктуры и многочисленных промышленных зон, предоставление адекватных площадей для торговли и высокотехнологичной промышленности, а также комфортных общественных пространств, безбарьерной среды обитания и т.д.

Многие из этих задач, в принципе, закреплены в общегородских планах развития. Стратегия социально-экономического развития Санкт-Петербурга до 2035 года ставит перед собой цель довести уровень жизни до сопоставимого с другими европейскими городами. При этом должно быть усилено значение СанктПетербурга как культурного центра, города науки, исследований и высоких технологий и, прежде всего, дальнейшее развитие его туристической привлекательности. Генеральный план, аналогичный плану землепользования в немецких муниципалитетах (нем. Flächennutzungsplan), определяет будущее распределение территорий, определяя их функциональное назначение: для промышленности, жилых зон, бизнеса и отдыха, а также зелёных зон и маршрутов. Тем не менее нет инструментов управления и координации пространственного развития города, которые обеспечивали бы качество строительства и культуру планирования. На данный момент не существует Перспективного плана развития города (нем. Leitbild), в котором определены пространственные границы и расположение градостроительных доминант - плана, в котором были бы обозначены акценты городского дизайна или установлены правила для структурного развития значимых мест с точки зрения пространства и функции, например, на набережных и площадях. Это тем более удивительно для города, чей генетический код состоит из особого пространственного порядка, взаимодействия широких осей, открытых пространств, периферийной застройки и представительных зданий.

\section{Город на воде}

Развитие города всегда было связано с водой. Дельта реки Невы с её протоками и каналами разделяет городскую территорию на 42-х острова, которые соединяют более чем 340 мостов. При основании города в 1703 году царь Петр Великий представлял себе зелёный город с бульварами, каналами, парками и садами. Они стали важными элементами нового в то время города, многие из них являются сейчас объектами всемирного наследия ЮНЕСКО. На протяжении всей истории на прибрежной территории, особенно на берегах Невы, строились важные здания. Пространства набережных являются предпочтительными районами развития и 
сегодня. Они обладают особыми качествами, но также нуждаются и в соблюдении особых требований. Набережные имеют особое значение для города, поэтому им уделено соответствующее внимание в общественных дискуссиях.

\section{Балтийская жемчужина}

К юго-западу от центра, на побережье Финского залива, находится «Балтийская жемчужина» - район с населением около 35000 человек, с жилыми домами, магазинами и общественными объектами, часть из которых была создана за счёт искусственного создания суши - намыва. Крупнейший на сегодняшний день китайский инвестиционный проект должен был быть завершен в 2008 году, но, как и многие другие проекты, он пострадал от финансового кризиса. На участке площадью 200 гектаров строится недвижимость площадью более одного миллиона квадратных метров с 14000 квартир и 600000 квадратных метров коммерческого использования [5]. Кроме того, предусмотрено строительство социальных объектов среди них четыре школы, семь детских садов и больница [6] (рис. 3).

В конкурсе на разработку проекта данного квартала приняли участие пять международных архитектурных фирм, проекты которых послужили основой для создания генерального плана: американская группа планирования HOK, английский консорциум «0ве Арэп энд Партнерс» (Ove Arup \& Partners) с ОМА, бельгийская компания «Ксавьер де Жетер Аршитектен» (Xaveer de Geyter Architecten), швейцарский офис «Свеко ФФНС» (Sweco FFNS) и санкт-петербургская рабочая группа, состоящая из архитектурных бюро: «Студия 44», «Земцов, Кондиайн и партнёры». Желанием заказчика было создание зелёного городского квартала в европейском стиле, Последовавшие затем заказы на проектирование получили только российские архитектурные бюро.

Площадь разделена на семь секций. Сегодня уже построены жилые кварталы: «Жемчужная премьера» с крупномасштабными жилыми блоками высотой от восьми до 19 этажей, «Жемчужная симфония» с террасированными зданиями изогнутой формы (оба квартала проектировал научно-исследовательский и проектный институт «ЛЕНИИПРОЕКТ»), жилой квартал «Жемчужный фрегат» со зданиями от 15 до 18 этажей (разработанный архитектурным бюро «Студия 17») и жилой квартал «Дудерхоф Клаб» (Duderhof Club) с искусственно созданным каналом, жилой район с двух- и трёхэтажными домами и таунхаусами, который был спроектирован петербургской архитектурной мастерской «АМЦ-ПРОЕКТ». В торговом комплексе «Жемчужная Плаза», расположенном в продолжении главной оси района и создающим «входное пространство» квартала, на площади 48000 кв. м. размещены магазины, рестораны, кинотеатры и другие объекты обслуживания, необходимые для жителей квартала. Восточнее расположено офисное здание со штаб-квартирой инвестора, которое представляет собой по форме полуоткрытую раковину с жемчужиной [7] (рис. 4).

Выгодное расположение на берегу залива не было использовано в должной мере. Ориентация квартала направлена вовнутрь, и первоначально запланированные общественные пространства были сокращены в пользу максимального использования территории под жилое строительство. Можно также спорить о дизайне квартала и благоустройстве. Тем не менее район адресован различным группам населения с предложением вариативной жилой архитектуры и широким набором коммунальныхуслуг. Существуют

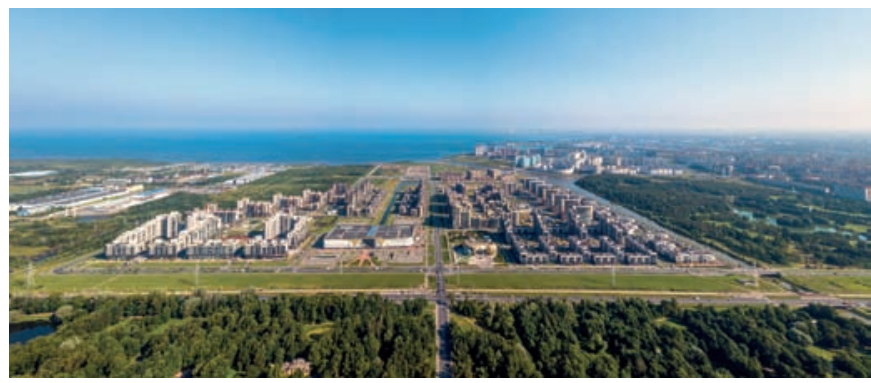

Рис. 3. Общий вид на территорию жилого района «Балтийская жемчужина» с юга. От торгового центра «Жемчужная плаза», расположенного слева, ведёт центральная ось на север (источник: фото из архива 3 АО «Балтийская жемчужина». 2018 год)

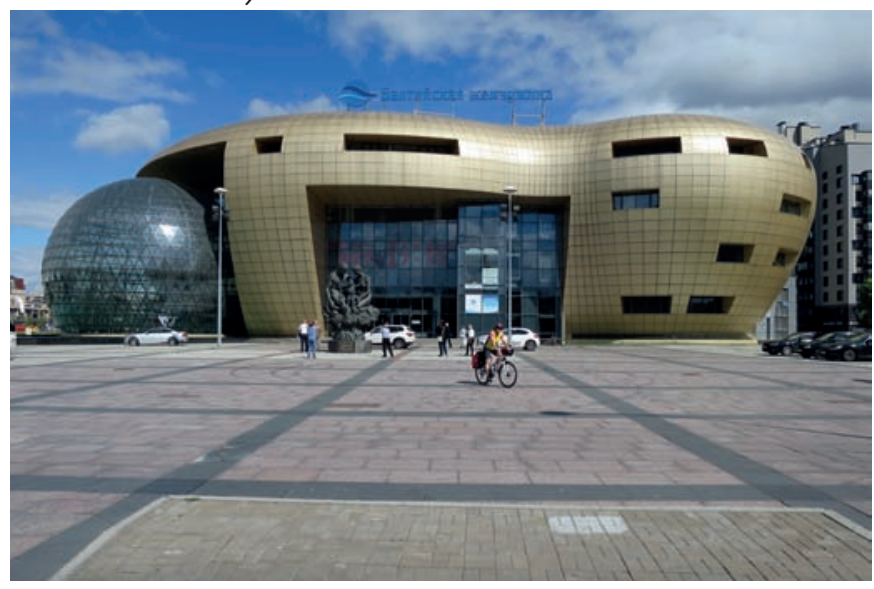

Рис. 40фисный центр инвестора представляет собой здание в виде полуоткрытой раковины с жемчужиной. Архитектурная мастерская «АМЦ-ПРОЕКТ». Фото Рюдигера Криша (Rüdiger Krisch). 2016 год

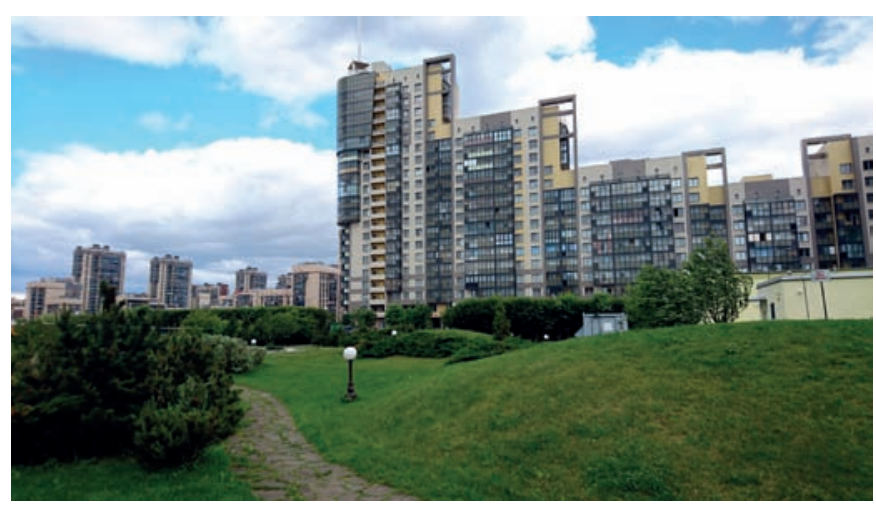

Рис. 5. Жилая среда отличается обилием зелёных зон. Фото Штефана Крэмера (Stefan Kraemer). 2016 год 


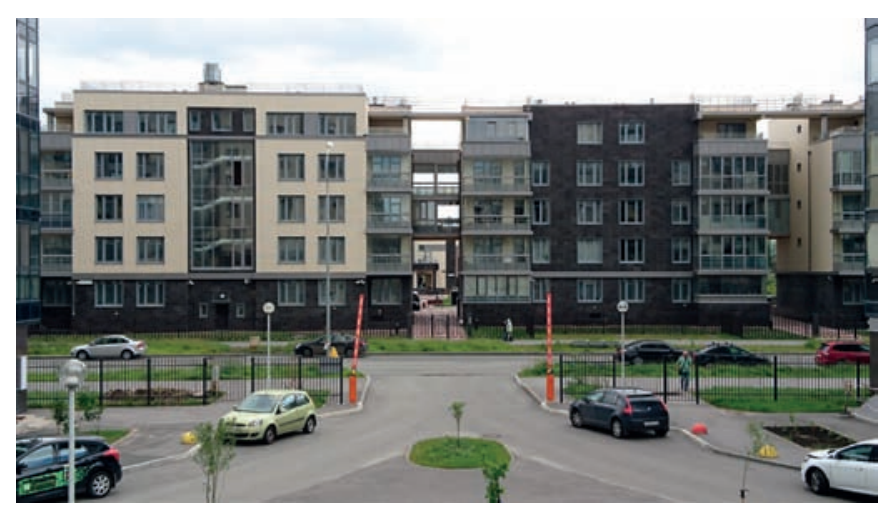

Puс. 6. Жилой комплекс «Дудерхоф Клаб» (Duderhof Club). Были установлены заборы, которые ограничивают желаемую проницаемость, Автор проекта: архитектурное бюро АМ Цыцина. Фото Штефана Крэмера. 2016 год

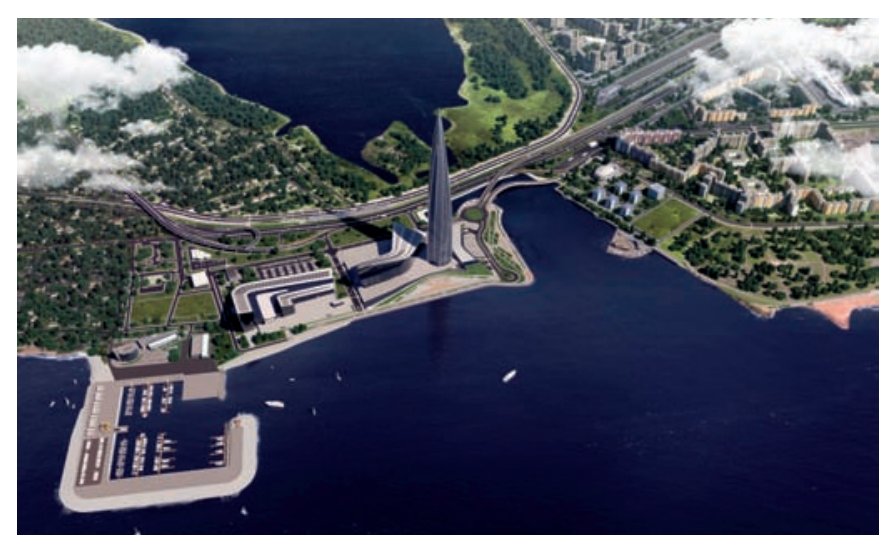

Puс. 7. Башня Газпрома - самая высокая башня в Европе (высота 462 м). Вокруг башни расположен комплекс коммерческих зданий с офисными помещениями, конгресс-центром и пристанью для яхт. Кроме того, запланированы и государственные учреждения. Визуализация (источник: официальный интернет-сайт «Лахта-центра»-https://lakhta.center/ru/)

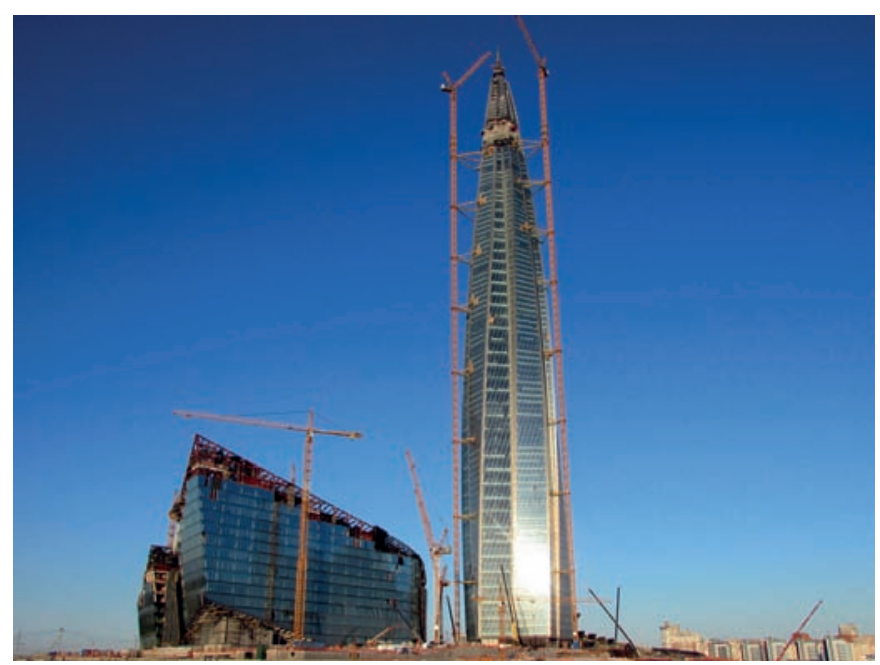

Puc. 8. Процесс строительства башни (источник: https:// upload.wikimedia.org/wikipedia/commons/2/23/Lakhta_ Center_orig.jpg) также предложения по использованию общественныхпространств и зданий, однако уже установлен ряд ограждений, которые уменьшают желаемый доступ на эти территории. Ещё одним недостатком является отсутствие рационального, удобного общественного транспорта для соединения нового района с центром города, где расположено большинство рабочих мест. Запланированное подключение к существующей сети метро может занять десятилетия. Было бы проще, быстрее и дешевле реализовать отдельные линии автобусов и трамваев, но этого ещё не произошло (рис. 5, 6).

\section{Лахта-центр}

«Лахта-центр» расположен в Приморском районе на северном побережье Невской губы и находится ещё на стадии строительства. В 2011 году ПАО «Газпром» приобрело территорию общей площадью 140000 кв. м для строительства штаб-квартиры своей компании. По мнению Газпрома этот центр должен стать сердцем многообещающего, устойчивого, пригодного для жизни района. Помимо офисных площадей планируется строительство научных и учебных заведений, конгресс-центра, кинотеатров и поликлиник, магазинов, ресторанов, кафе и других общественных объектов. Первоначально размещение объекта было запланировано в историческом центре города (Красногвардейский район). Это вызвало недовольство широкой общественности, что отразилось в средствах массовой информации, где появилось большое количество критических высказываний. С момента запуска проекта в 2006 году Газпром подвергался жёсткой критике за многочисленные нарушения: от использования платных лоббистов для участия в общественных слушаниях и фальсификации опросов общественного мнения до публикации платных, комплементарно-направленных новостей, в которых поддерживался проект в местных СМИ [8].

В 2006 году инвестор провёл международный архитектурный конкурс, победитель которого - британский архитектурный офис «РМЖМ» (RMJM), разработал проект, который смог, по мнению жюри, объединить необходимые функции, ориентированные на будущее развитие компании, с архитектурными традициями Петербурга. Для этого цокольные этажи здания и окружающая высотное здание застройка выполнена в горизонтальных линиях, характерных для Санкт-Петербурга. 462-метровая башня «Лахта-центр», которая, как считает Газпром, должна стать новой архитектурной достопримечательностью Санкт-Петербурга, до сих пор является камнем преткновения для многих споров, дискуссий и обсуждений. Даже с учётом того, что здание находится за пределами охраняемой территории исторического центра Санкт-Петербурга, вершину башни можно увидеть со многих точек центральной части города и с акватории Финского залива. Влияние башни на исторический центр было очевидно для таких архитекторов как Норман Фостер, Кишо Курокава и Рафаэль Виньоли, и именно поэтому они покинули жюри конкурса. После дальнейшего давления со стороны населения и предупреждений со стороны Комитета всемирного наследия ЮНЕСКО, предупредившем об угрозе утраты исторического си- 
луэта города при строительстве башни, проект был перенесён на северо-западную окраину города [9] (рис. 7, 8).

В последние годы в этом районе начались работы по благоустройству, в том числе строительство парка, посвященного 300-летию Санкт-Петербурга, однако строительство линии метро и новой железнодорожной станции, на которой должны останавливаться современные поезда, не предвидится. Еще неизвестно, достаточно ли награждения золотой медалью «Леед» (Leed) за стандарт экологического строительства, чтобы проект высотного здания считался успешным, была воплощена в жизнь обещанная Газпромом идиллия устойчивого развития района. Жители прилегающих кварталов опасаются, что престижный проект сделает эту территорию инвестиционно-привлекательной для других инвесторов и это вызовет повышение цен [10].

\section{Морской фасад}

Реализация самого на сегодняшний день крупномасштабного проекта проводится в западной части Васильевского острова, находящегося на прибрежной территории в шести километрах от исторического центра города. Здесь планируется строительство делового и жилого района со школами, социальными объектами, открытыми площадками для спорта и отдыха. Новый район должен стать привлекательным как для жителей, так и для гостей города. Это один из крупнейших проектов государственно-частного партнёрства в Санкт-Петербурге, финансируемый Российской Федерацией, городом Санкт-Петербург и частными застройщиками.

Проекты по созданию новой прибрежной зоны были разработаны ещё в 1960-х годах. Для квартала численностью 150000 человек было создано путём намыва почти 200 гектаров новой площади. И уже тогда особая ценность площади застройки привела к тому, что её плотность была почти в полтора раза выше обычной на тот период. В начале 1980 -х годов в этом месте были построены 9-12-этажные здания. Широкая зелёная эспланада (упирающаяся в залив) с гранитной береговой стенкой образовала главную ось, обращённую к западу (рис. 9).

В основе сегодняшнего планирования и в конечном счёте двигателем развития территории, начиная с 1990-х годов, выступали соображения по строительству западного обходного пути для освобождения центра Санкт-Петербурга - так называемого Западного скоростного диаметра (ЗСД). Уже сегодня северная и южная части города соединены с помощью вантового моста, пересекающего Финский залив и идущего вдоль западного побережья Васильевского острова [11].

В 2005 году среди пяти российских участников был проведён конкурс по городскому планированию, победителем которого стал московский архитектор Владимир Плоткин и его архитектурное бюро «Резерв». Другие участники конкурса, в том числе «Студия 17» и архитектурное бюро «Сергей Киселёв и партнёры», представили совершенно разными предложения по дизайну морского фасада.

В 2006 году инвестор принял решение об изменении проекта. Британско-американский офис «Генслер» (Gensler) разделил территорию на северный офисный район и южную жилую зону с высотой застройки до 200 метров. Доминанта высотой 300 метров должна была возвышаться в устье реки Смоленки, обозначая «вход в озеро». В 2014 году городской совет принял новый генеральный план, разработанный санкт-петербургским архитектурным бюро «Союз-55», который значительно увеличил долю жилой площади за счёт сокращения других видов использования проектируемой застройки. Идея размещения каналов, запланированных в первоначальном проекте, была отклонена (рис. 10).

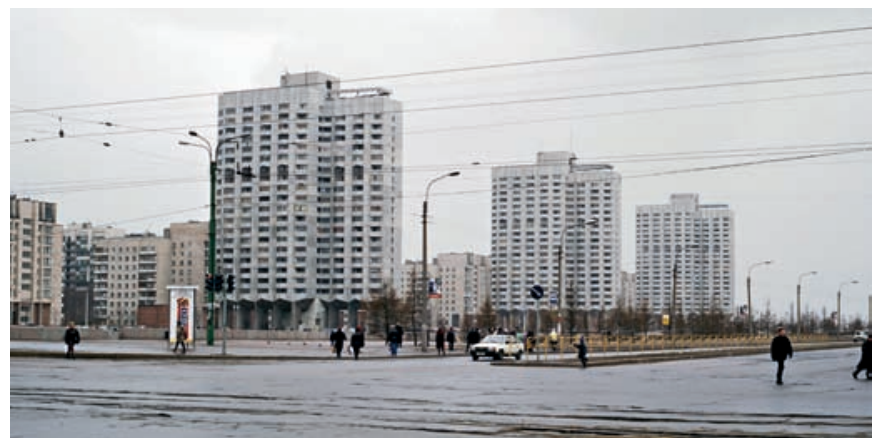

Pис. 9. Здания вдоль улицы Новосмоленской, построенные в 1980-х годах. Фото Барбары Энгель

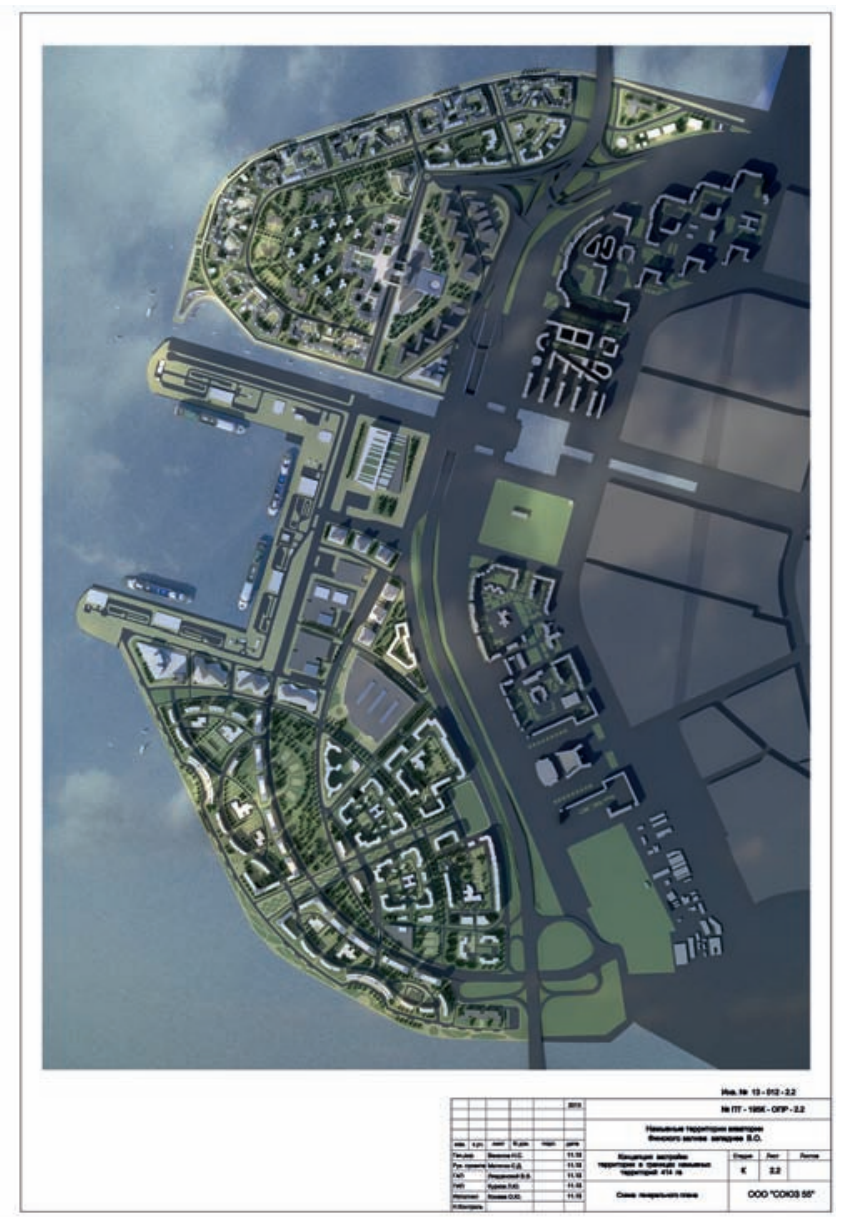

Рис. 10. Проект застройки Васильевского острова. Архитектурное бюро «Союз 55». 2014 год (источник: из архива 3 АО «Терра Нова») 
В 2015 году был проведён международный градостроительный конкурс для южной части Васильевского острова. Победу в конкурсе одержала команда из двух голландских офисов «КСАП Аркитектс и Планнерс» (КСАР Architects \& Planners) и «Оранж Аркитектс» (Orange Architects). После конкурса для адаптации реализации голландского проекта к российским строительным стандартам была выбрана архитектурная мастерская «А-Лен» (A-Len) (СанктПетербург) [12].

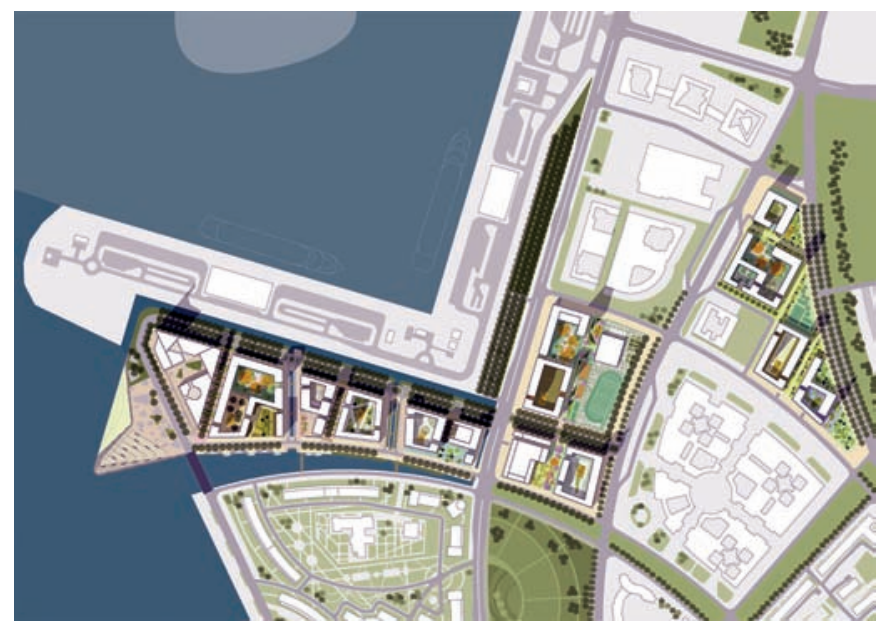

Рис. 11. Проект архитектурного бюро «КСАП+Оранж Аркитектс» (KCAP + Orange Architects) предусматривает композицию из шести блоков и предусматривает чёткие общественные и частные зоны [источник: из архива архитектурного бюро «КСАП+Оранж Аркитектс» (КСАР + Orange Architects)]

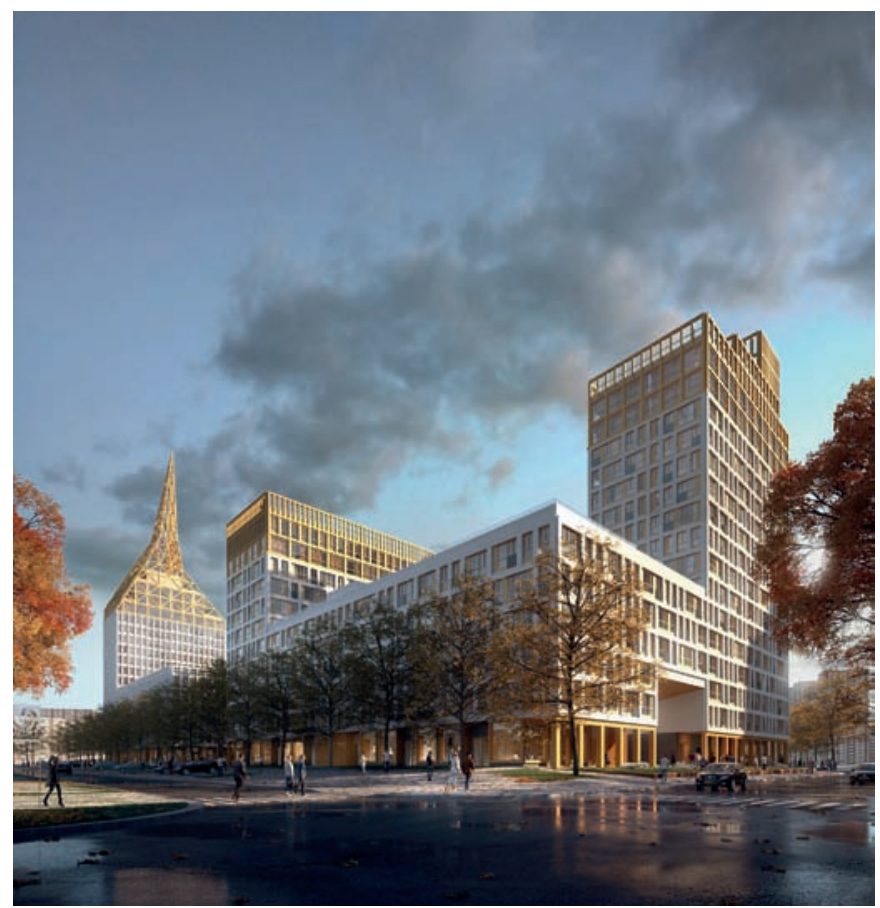

a)
Проект «Голден-Сити» (Golden City), разработанный архитектурными бюро «КСАП +0ранж Аркитектс» (КСАР + Orange Architects), композиционно состоит из шести жилых блоков, которые, благодаря своей пространственной организации, создают чётко распознаваемые общественные и частные зоны. Жилые этажи с фасадами белого цвета возвышаются над цокольными этажами с отделкой цвета золота, где расположены магазины, офисы и объекты инфраструктуры. В районе предусмотрена инфраструктура, обеспечивающая широкий спектр услуг, а также взаимосвязь с окружающими районами (рис. 11).

Асимметричный угловой акцент в виде башен с золотыми шпилями до 21 этажа - по аналогии с важными зданиями в старом городе Санкт-Петербурге - формирует выразительный силуэт. Из квартир на верхних этажах открывается вид на море и центр города. Изменение высоты зданий играет существенную роль для восприятия города, для исторического центра которого характерен однородный горизонтально ориентированный силуэт с несколькими доминантами. Это особенно горячо обсуждалось последние годы в связи со строительством Башни Газпрома. В результате строительные нормы и правила были изменены таким образом, чтобы купола, башни, кровля и любые технические конструкции не превышали высоту, указанную в Генеральном плане, и соответствовали указанным там нормам. При этом в «Голден-Сити» некоторые шпили пришлось уменьшить по высоте, при этом силуэт застройки нового квартала изменился и стал более сдержан по сравнению с первоначальным проектом (рис. 12).

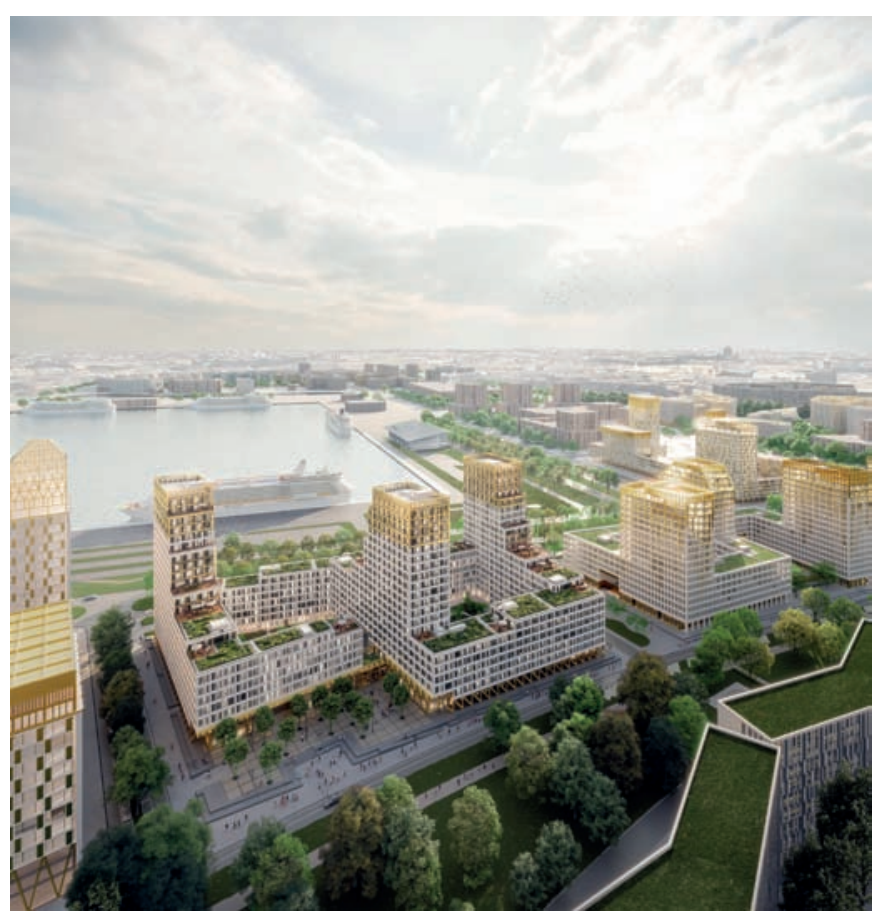

б)

Рис. 12. Визуализация городского квартала с сооружениями и башнями с отделкой цвета золота ]источники: из архива архитектурного бюро «КСАП+Оранж Аркитектс» (КСАP + Orange Architects)] 
Каналы, предложенные проектом «КСАП+Оранж Аркитектс» (KCAP + Orange Architects), которые воссоздавали облик «Северной Венеции», соорудить не удалось, так как город и инвестор не нашли организационно-технического решения для их реализации, поскольку воды в Финском заливе имеют федеральный статус и не входят в зону ответственности администрации города, являющегося заказчиком. Но тем не менее даже без дополнительных водных пространств дизайн проекта отличается привлекательными местами общего пользования и высококачественной жилой средой. Здесь можно найти различные предложения для спорта и отдыха. Дворы и сады создают защиту от холодных морских ветров, они индивидуально спроектированы и переосмысливают традиции всемирно известных дворцовых садов. «Голден-Сити» обещает быть не только интересной «входной-парадной» зоной города, но и достойным жилым районом - привлекательным как для жителей города, так и для туристов Санкт-Петербурга (рис. 13).

Петербургская «Студия 44» ведёт проектирование объекта на участке, граничащем с жилым кварталом «Голден-Сити» на юге, - в совершенно другом масштабе. Четыре жилых блока гигантских размеров расположены на полосе протяжённостью около двух километров. Мега-силуэт состоит из 16-20-этажных домов, выходящих к воде в полукруглой, угловой и линзовидной геометриях, при этом открывается вид на 14-этажные дома во втором ряду. Проект получил высокую оценку на Градостроительном совете города, но также подвергся критике со стороны архитекторов и жителей, которые назвали его «Шушары 2» ещё до того, как он был построен, ссылаясь на однообразное большое поселение Шушары на юге города [13] (рис. 14, 15).

В соседнем квартале на востоке уже построены огромные здания жилых комплексов: «Капитан Немо», «Колумб» и «Артур Грей», которые не только не сомасштабны человеку, но и качество их архитектуры также невысоко. Плюс ко всему, всё это усугубляется шумом и выхлопными газами со стороны городской автомагистрали, движение по которой направлено из центра в сторону области. Её строительство повысило интенсивность потока автотранспорта, так как многие жители, перемещающиеся с запада и юга Санкт-Петербурга как в сторону центра, так и в сторону новых кварталов, считают данный маршрут кратчайшим [11] (рис. 16).

\section{«Third Petersburg» (Третий Петербург)}

В Советском Союзе природные территории рассматривались в первую очередь как ресурс для промышленности и сельского хозяйства, предполагалось, что этот ресурс неисчерпаем. Преобладал потребительский интерес, и основное внимание уделялось эксплуатационному использованию природной среды, а не её поддержанию и ревалоризации.

«Балтийская Жемчужина», «Морской фасад», «ЛахтаЦентр» - проекты на вновь созданных и вновь освоенных территориях, которым по-прежнему отдаётся предпочтение по сравнению с развитием уже интегрированных мест. На них нет заметного использования ландшафта и открытых

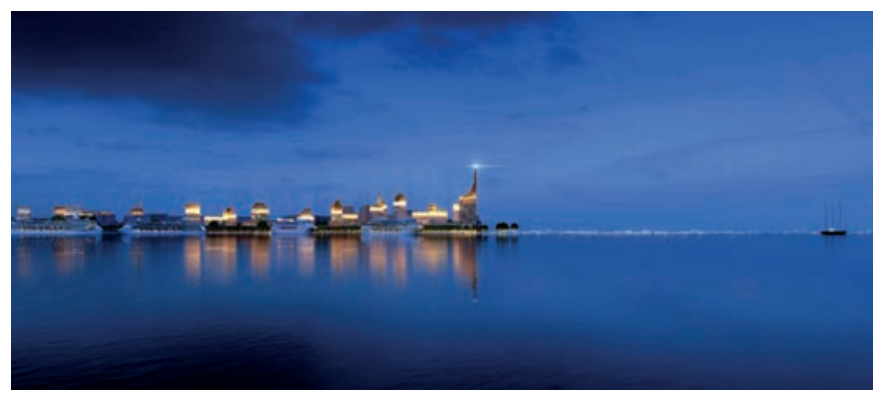

Рис. 13. Визуализация силуэта «Голден-Сити». Здания должны ярко светиться в темноте (источник: из архива архитектурного бюро «КСАП+Оранж Аркитектс» (КСАР + Orange Architects).

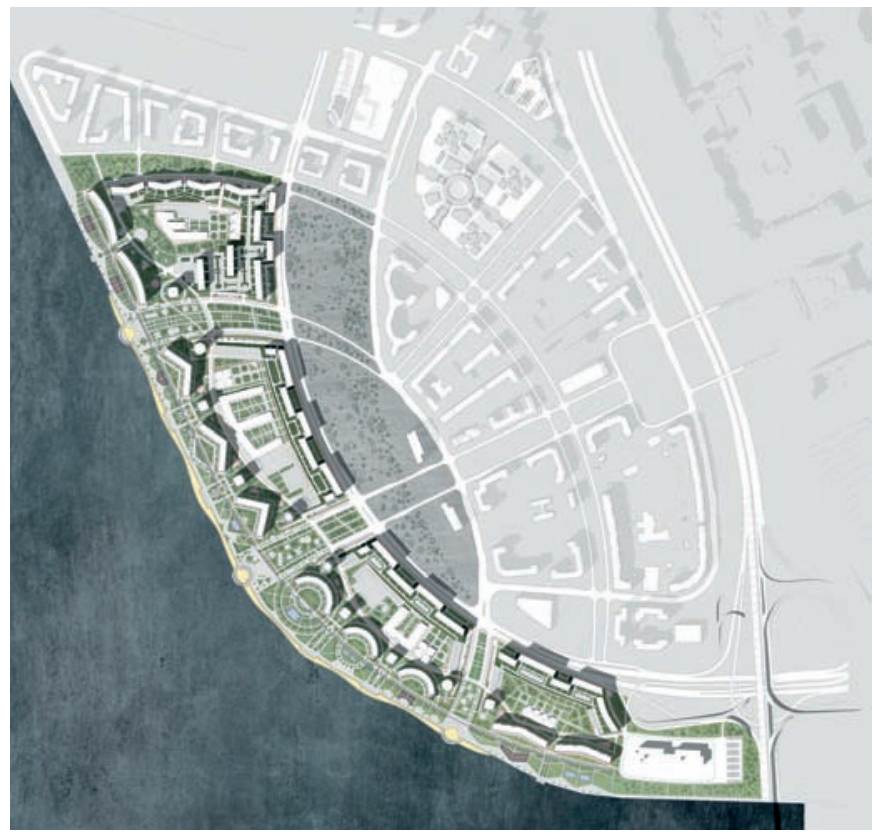

Рис. 14. Проект архитектурного бюро «Студия 44» представлен широкоформатными блоками (источник: из архива архитектурного бюро «(тудия 44»)

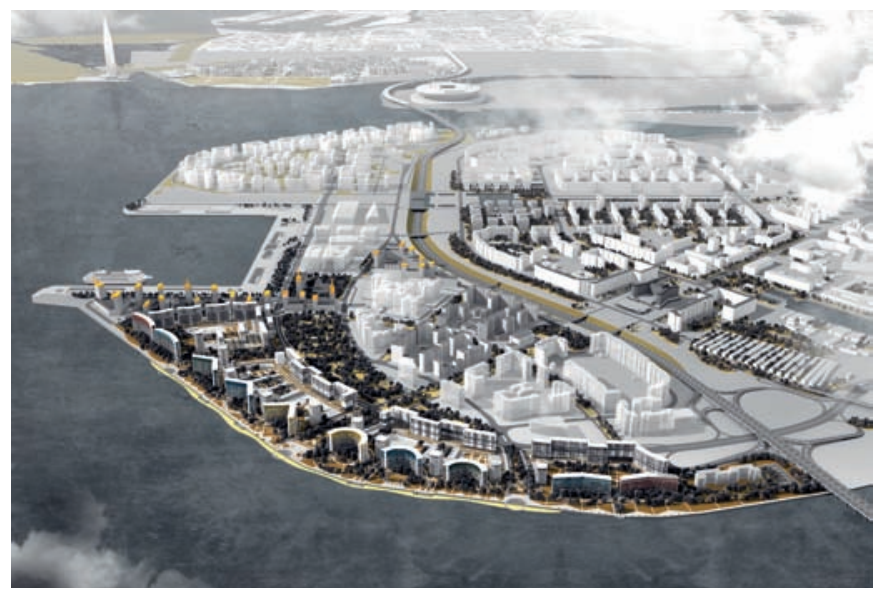

Рис. 15. Модель Васильевского острова с юга. На переднем плане застройка по проекту «Студии 44», на заднем плане - башня Газпрома. 2017 год (источник: из архива архитектурного бюро «(тудия 44») 
пространств. Очевидно, что «устойчивость, как принцип градостроительной деятельности, в Санкт-Петербурге не является приоритетным направлением, возможно, это является результатом отсутствия обмена опытом с другими городами, в частности, Санкт-Петербург не был вовлечён в процессы программного плана 00H «Повестка дня на XXI век» (англ. Agenda 21). В настоящее время существует план адаптации застройки, ориентированный на изменение климата, однако его реализации мешает игнорирование экологических аспектов в других стратегических планах города [14]. Площадь СанктПетербурга - 1440 квадратных километров - это огромная территория! Возникает вопрос - почему для развития новых

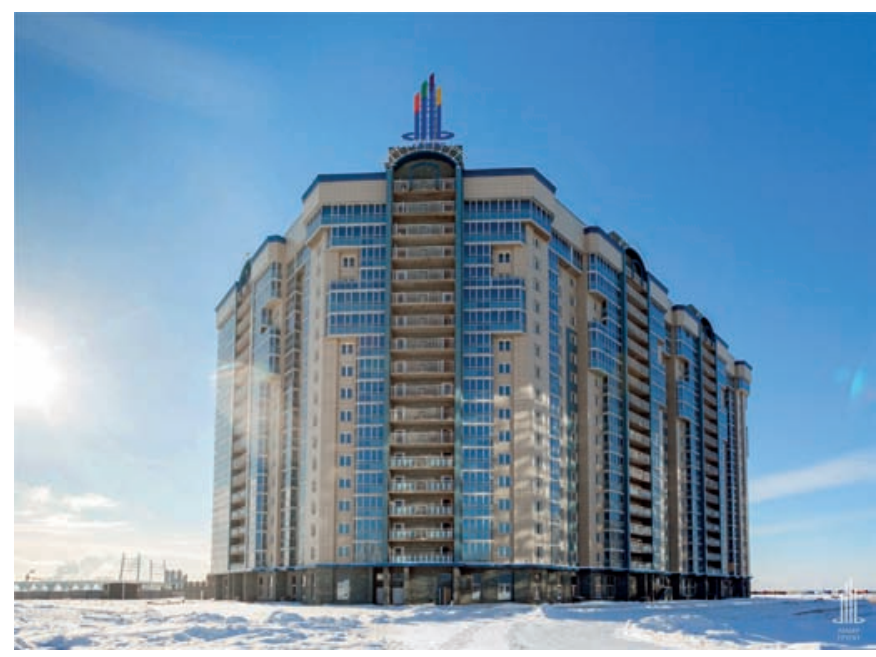

Рис. 16. К востоку от «Голден-Сити» уже построены большие здания, такие как жилой блок» Капитан Немо» [источник: из архива компаний 3 AO «Терра Нова», «Севен Санс Девелопмент» (Seven Suns Development), «Лuдер [руnn», (Lider Grupp)] кварталов создают искусственные земли вместо того, чтобы переустроить существующие.

Ресурсом для рекультивации являются 12000 квадратных километров промышленных зон, которые окружают историческое ядро, отделяя центр от основных жилых районов. Являясь в тот период признаком процветания и роста, так называемый «Серый пояс» сейчаси в значительной степени утратил свою функцию производственного объекта. Заброшенные территории и такие крупные объекты, как железнодорожные пути и автодороги, занимают обширную площадь, в то же время там имеется уже развитая инфраструктура: водопровод, электричество, газопроводы. Данная территория располагает большим потенциалом для проектирования новых жизненных пространств и обеспечения условий труда.

В 2016 году в городе стартовал международный конкурс на разработку первичных идей по реорганизации промышленной зоны. Архитектурный проект «Третий Петербург», представленный голландским офисом «МЛА+» (MLA+), идея которого заключается в выявлении так называемой «ДНК района» с его промышленной историей. Старые железнодорожные пути превращаются в линейные парки, заброшенные промышленные здания становятся ключевыми факторами будущего развития. Новые функции этих территорий, такие как университеты, культурные объекты и другие виды общественного пользования, интегрируются и создают сеть новых центров. Общественные пространства и парки, а также велосипедные и пешеходные дорожки и оживлённые речные пространства и каналы образуют новую пространственную структуру (рис. 17).

До сих пор неясно, будут ли и когда следующие этапы планирования. Следует надеяться, что импульсы от проектов из России, Финляндии, Норвегии и Нидерландов будут ис-

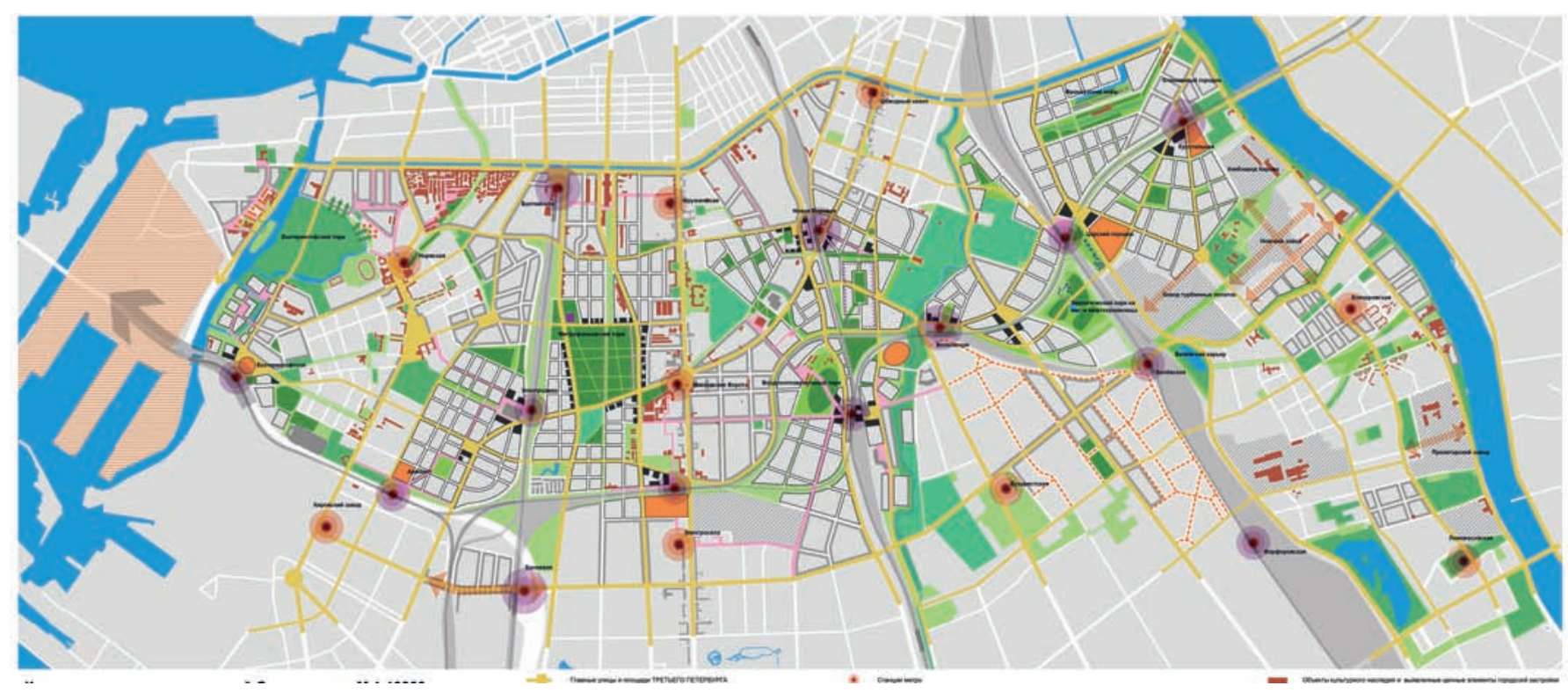

Рис. 17. Конкурсный проект архитектурного бюро «МЛА+» (MLA+): трансформация южной части индустриального пояса Санкт-Петербурга (источник: из архива. Комитета по градостроительству и архитектуре Правительства СанктПетербурга. Результаты конкурса: «Серый пояс. Преобразование». 2016 год) 
пользованы для продвижения амбициозного проекта, столь важного для города. Нужно не только разрабатывать новые строительные нормы и правила зонирования, но и менять парадигму городского планирования. Требования к городу, жилым зданиям и рабочей среде давно изменились, и растёт спрос на организацию пешеходных пространств и стимулирование пешеходного движения как лучшего варианта передвижения, а также на другую форму планирования. В Санкт-Петербурге у граждан всё чаще возникает желание иметь право голоса в выборе дизайна своего города и играть активную роль в его формировании. Об этом свидетельствуют не только акции протеста, такие как, например, акция против строительства «Лахта-центра», но также создание многих неправительственных организаций, появившихся в последние годы, и проявление инициатив: для улучшения общественного пространства, создания сети велодорожек, увеличения количества озеленённых пространств и многое другое, что могло бы способствовать повышению устойчивости города.

Исторический Санкт-Петербург - это впечатляющее произведение искусства, созданное по единому грандиозному плану. Однако особая прелесть Санкт-Петербурга в XXI веке заключается во множестве небольших инициатив и проектов горожан, которые делают Санкт-Петербург - помимо существующих генеральных планов и крупных инвестиций - образцом для других российских городов. Такие места, как креативное пространство «Тайга» (Creative Space «Taiga»), «Этажи» и «Красный Треугольник», являются доказательством обновления города, которое, мы надеемся, будет успешным, прежде чем жители Санкт-Петербурга откроют для себя другие комфортные города на Балтийском море.

\section{Лumepamypa}

1. Vatin, N. Analysis of the real estate market of St. Petersubrg // N. Vatin, 0. Gamajunova, D. Nemova // Applied Mechanics and Materials. - 2014. - Vols. 638-640. - P. 2460-2464.

2. Voskresenskaya, E. Strategic priorities for development of housing construction and renovation sector [Электронный ресурс] // E. Voskresenskaya, L. Vorona-Silvinskaya, L. Achba // E3S Web Conference, Vol. 91, 2019. "Topical Problems of Architecture, Civil Engineering and Environmental Economics" (TPACEE 2018). - Режим доступа: https://www. e3s-conferences.org/articles/e3sconf/abs/2019/17/e3sconf_ tpacee2019_05010/e3sconf_tpacee2019_05010.html (дата обращения: 22.01.2020). DOI: 10.1051/e3sconf/20199105010

3. Малышева, Б. За пять лет в Петербурге построят почти 14 млн кв. м. жилья [Электронный ресурс] / Б. Малышева // Fontanka. ru. - Режим доступа: https://www.fontanka. ru/2019/05/16/055/ (дата обращения 18.01.2020).

4. Мурашко, 0. Выбираем квартиру в новых панельных домах [Электронный ресурс] / 0. Мурашко // BN.RU [сайт]. - Режим доступа: https://www.bn.ru/gazeta/articles/89146/ (дата обращения 18.01.2020).
5. Dixon, M. Dixon Megan Chinese Developers and Russian Urban Planning / M. Dixon // Russian Analytical Digest. - 2010. - № 85. - P. 5-7.

6. Dixon, M. The Baltic Pearl in the Window to Europe: St. Petersburg's Chinese Quarter / M. Dixon // Dissertation for the degree of Doctor of Philosophy Department of Geography and the Graduate School of the University of Oregon. - Oregon, 2008. - $346 \mathrm{p}$.

7. Кравцова, И. Китайцы строить не спешат / И. Кравцова [Электронный ресурс] // Rosbalt [сайт]. - Режим доступа: https://www.rosbalt.ru/piter/2009/08/11/662620.html (дата обращения 09.02.2020).

8. Молодцова, Л. Микрорайон «Балтийская жемчужина» проект комплексного освоения территории [Электронный ресурс] / Л. Молодцова // Bpearl.net [сайт]. - Режим доступа: https://bpearl.net/o-proekte/celiy-mir/ (дата обращения 13.02.2020).

9. Stolyarova, G. St. Petersburg Skyscraper Approval Prompts Protests [Электронный ресурc] / G. Stolyrova // TheMoscowTimes [web]. - Режим доступа: https://www.themoscowtimes. com/2012/09/03/st-petersburg-skyscraper-approval-promptsprotests-a17481 (дата обращения 13.02.2020).

10. Архипов, И. Как Охту на Лахту меняли [Электронный ресурс] / И. Архипов // Expert.ru [сайт]. - Режим доступа: https://expert.ru/exprealty/2011/02/kak-ohtu-na-lahtumenyali/ (дата обращения: 12.02.2020).

11. Mijnssen, I. 462 Meter Prestige Электронный ресурс] / I. Mijnssen // NZZ Folio/ - Режим доступа: https://folio. nzz.ch/2017/dezember/462-meter-prestige (дата обращения 27.01.2020).

12. Lavrov L. Molotkova, E. Marine Facade, Western HighSpeed Diameter and Vaisylevsky Island as a part of the Saint Petersburg Historical Center / L. Lavrov, E. Molotkova // Architecture and Engineering. - 2019. - Vol. 4. - Iss. 2. - P. 40-54. (In Engl.)

13. Петухова, E. Парадный фасад [Электронный ресурс] / Е. Петухова // Archi.Ru [сайт]. - Режим доступа: https://archi. ru/russia/78419/paradnyi-fasad (дата обращения 31.01.2020).

14. Зеликова, E. Как из морского фасада делают Шушары-2 [Электронный ресурс] / Е. Зеликова // Fontanka. Ru [сайт]. - Режим доступа: https://www.fontanka.ru/2017/11/08/105/ (дата обращения 08.02.2020).

15. Krellenberg, K. Bergsträßer, H. Bykova, D. Kress, N. Tyndall, K. Urban Sustainability Strategies Guided by the SDGs - A Tale of Four Cities / K. Krellenberg, H. Bergsträßer, H. Bykova // Sustainability. - 2019. - № 11 (4). - 1116. - Режим доступа: https://doi.org/10.3390/su11041116 (дата обращения 02.02.2020).

\section{References}

1. Vatin N. Gamajunova 0. Nemova D. Analysis of the real estate market of St. Petersubrg. In Applied Mechanics and Materials, 2014, Vols. 638-640, pp. 2460-2464. (In Engl.) 
2. Voskresenskaya E. Vorona-Silvinskaya L., Achba L. Strategic priorities for development of housing construction and renovation sector. E3S Web Conference, Vol. 91, 2019. "Topical Problems of Architecture, Civil Engineering and Environmental Economics" (TPACEE 2018). Access mode: https://www. e3s-conferences.org/articles/e3sconf/abs/2019/17/e3sconf_ tpacee2019_05010/e3sconf_tpacee2019_05010.html (accessed 22.01.2020). DOI: 10.1051/e3sconf/20199105010 (In Engl.)

3. Malysheva B. Za pyat'let $\vee$ Peterburge postroyat pochti $14 \mathrm{mln} \mathrm{kv.} \mathrm{m.} \mathrm{zhil'ya} \mathrm{[For} \mathrm{five} \mathrm{years} \mathrm{in} \mathrm{St.} \mathrm{Petersburg} \mathrm{will} \mathrm{build}$ almost 14 million square meters]. Website "Fontanka.ru". Access mode: https://www.fontanka.ru/2019/05/16/055/ (accessed 18.01.2020). (In Russ.)

4. Murashko 0. Vybiraem kvartiru v novykh panel'nykh domakh [Choosing an apartment in new panel houses]. Website BN.RU. Access mode: https://www.bn.ru/gazeta/ articles/89146/ (accessed 18.01.2020). (In Russ.)

5. Dixon, M. Dixon Megan Chinese Developers and Russian Urban Planning. In: Russian Analytical Digest, 2010, no. 85, pp. 5-7. (In Engl.)

6. Dixon, M. The Baltic Pearl in the Window to Europe: St. Petersburg's Chinese Quarter. Dissertation for the degree of Doctor of Philosophy Department of Geography and the Graduate School of the University of Oregon. Oregon, 2008, 346 p.

7. Kravtsova I. Kitaitsy stroit' ne speshat [The Chinese are in no hurry to build]. Website "Rosbalt". Access mode: https:// www.rosbalt.ru/piter/2009/08/11/662620.html (accessed 09.02.2020). (In Russ.)

8. Molodtsova, L. Mikroraion «Baltiiskaya zhemchuzhina» - proekt kompleksnogo osvoeniya territorii [Baltic Pearl" - a project of integrated development of the territory]. Website
"Bpearl.net". Access mode: https://bpearl.net/o-proekte/ celiy-mir/ (accessed 13.02.2020). (In Russ.)

9. Stolyarova G. St. Petersburg Skyscraper Approval Prompts Protests [St. Petersburg Skyscraper Approval Prompts Protests]. Website "TheMoscowTimes". - Access mode: https://www. themoscowtimes.com/2012/09/03/st-petersburg-skyscraperapproval-prompts-protests-a17481 (accessed 13.02.2020). (In Russ.)

10. Arkhipov I. Kak Okhtu na Lakhtu menyali [How they changed 0khta to Lakhta]. Website "Expert.ru". Access mode: https://expert.ru/exprealty/2011/02/kak-ohtu-na-lahtumenyali/ (accessed 12.02.2020). (In Russ.)

11. Mijnssen, I. 462 Meter Prestige. Website "NZZ Folio". Access mode: https://folio.nzz.ch/2017/dezember/462-meterprestige (accessed 27.01.2020). (In Russ.)

12. Lavrov L. Molotkova, E. Marine Facade, Western HighSpeed Diameter and Vaisylevsky Island as a part of the Saint Petersburg Historical Center. In: Architecture and Engineering, 2019, Vol. 4, Iss. 2, pp. 40-54. (In Engl.)

13. Petukhova, E. Paradnyi fasad [Front facade]. Website "Archi.Ru". Access mode: https://archi.ru/russia/78419/ paradnyi-fasad (accessed 31.01.2020). (In Russ.)

14. Zelikova, E. Kak iz morskogo fasada delayut Shushary-2 [How Shushary-2 is made from the sea facade]. Website "Fontanka.ru". Access mode: https://www.fontanka. ru/2017/11/08/105/ (accessed 08.02.2020). (In Russ.)

15. Krellenberg, K. Bergsträßer, H. Bykova, D. Kress, N. Tyndall, K. Urban Sustainability Strategies Guided by the SDGs - A Tale of Four Cities. In: Sustainability, 2019, no. 11 (4), 1116. Access mode: https://doi.org/10.3390/su11041116 (accessed 02.02.2020). (In Engl.)

Энгель Барбара (Карлсруэ, Германия). Доктор инженерии, профессор. Заведующая кафедрой международного урбанизма факультета архитектуры Технологического института г. Карлсруэ (Энглерштрассе 11, 76133, Карлсруэ). Эл. почта: barbara. engel@kit.edu.

\section{при участии:}

Анастасия Малько (Иркутск). Доктор инженерии. Научный сотрудник Института архитектуры, строительства и дизайна ФГБОУ В0 «Иркутский национальный исследовательский технический университет» (664074, Иркутск, ул. Лермонтова, 83. ИРнИТУ). Эл. почта: anastasiavmalko@gmail.com.

Engel Barbara. Doctor of Engineering, Professor, Head of Chair for International Urbanism, Faculty of Architecture, Karlsruhe Institute of Technology (11 Englerstrasse, Karlsruhe, 76133). E-mail: barbara.engel@kit.edu.

with the participation:

Anastasia Malko (Irkutsk). Doctor of Engineering, Researcher at the Institute of Architecture, Construction and Design of Irkutsk National Research Technical University (83, Lermontova st. Irkutsk,664074. IRNITU). E-mail: anastasiavmalko@gmail.com. 